\title{
УДК 330.1.003
}

Калайтан T. В., ORCID: 0000-0003-4774-4990, Researcher ID: F-5828-2019, к.е.н., доиент, доцент кафедри аудиту, аналізу та оподаткування, Львівський торговельноекономічний університет, м. Львів

Шурпенкова Р. К.,

ORCID: 0000-0002-8825-2389, Researcher ID: G-5148-2019,

к.е.н., дочент, дочент кафедри обліку і оподаткування, ДВНЗ “Університет банківської справи”, Львівський навчально-науковий інститут, м. Львів

Сарахман O. M.,

ORCID: 0000-0002-8793-592X, Researcher ID: G-7137-2019,

к.е.н., доиент, доиент кафедри обліку і оподаткування, ДВНЗ “Університет банківської справи”, Львівський навчально-науковий інститут, м. Львів

\section{РЕЗЕРВИ ЗРОСТАННЯ ЕФЕКТИВНОСТІ ЗОВНІШНЬОЕКОНОМІЧНОЇ ДІЯЛЬНОСТІ ПІДПРИЕМСТВА}

\begin{abstract}
Анотація. Досліджено теоретичні та практичні підходи щцодо виявлення резервів зростання ефективності зовнішньоекономічної діяльності вітчизняних підприємств. Обірунтовано сутність, умови формування та складові організаційно-економічного механізму визначення ефективності зовнішньоекономічної діяльності підприємств. Досліджено два методологічні підходи щзодо визначення ефективності зовнішньоекономічної діяльності підприємств. Один із них трунтується на розрахунку загального показника ефективності зовнішньоекономічної діяльності підприємства - прибутковості зовнішньоторговельних операчій. Інший - полягає в обчисленні ефективності окремих укладених зовнішньоторговельних угод. Аргументовано вибір методичних підходів щзодо аналізу зовнішньоекономічної діяльності підприємств і розроблено методику проведення такого аналізу, яка трунтується на застосуванні певних економіко-статистичних та економіко-математичних методів. Визначено систему оціночних показників та критерії ефективності зовнішньоекономічної діяльності підприємств шляхом розрахунку показників економічної ефективності та показників ефекту. Накреслено основні напрями пошуку резервів: ресурсний, технологічний, організачійний.
\end{abstract}

Ключові слова: резерви, зовнішньоекономічна діяльність, ефективність, підприємство, аналіз.

Kalaitan T. V., ORCID: 0000-0003-4774-4990, Researcher ID: F-5828-2019,

Ph.D., Associate Professor, Associate Professor of the Department of Audit, Analysis and Taxation, Lviv University of Trade and Economics, Lviv

Shurpenkova R. K.,

ORCID: 0000-0002-8825-2389, Researcher ID: G-5148-2019,

Ph.D., Associate Professor, Associate Professor of the Department of Accounting and Taxation, State Higher Educational Institution "Banking University", Lviv Educational-Scientific Institute, Lviv

Sarahman O. M., ORCID: 0000-0002-8793-592X, Researcher ID: G-7137-2019,

Ph.D., Associate Professor, Associate Professor of the Department of Accounting and Taxation, State Higher Educational Institution "Banking University", Lviv Educational-Scientific Institute, Lviv 


\title{
RESERVES FOR GROWTH OF THE FOREIGN ECONOMIC ACTIVITY EFFICIENCY OF THE ENTERPRISE
}

\begin{abstract}
The theoretical and practical approaches concerning revealing the reserves of growth of foreign economic efficiency of domestic enterprises activity are investigated. The essence, conditions of formation and components of organizational and economic mechanism of efficiency determination of enterprises foreign economic activity have been substantiated. Two methodological approaches to determining the efficiency of enterprises foreign economic activity are investigated. One of which is based on the calculation of the overall indicator of the efficiency of foreign economic activity of the enterprise - the profitability of foreign trade operations. The other one is based on the calculation the effectiveness of particular concluded foreign trade agreements. The choice of methodological approaches has been argued as to the analysis of enterprises foreign economic activity, the technique of carrying out of such analysis has been elaborated which is based on application of particular economic-statistical and economicmathematical methods. The system of estimated indicators has been defined, as well as the criteria of enterprises foreign economic activity efficiency by calculation of economic efficiency indicators and indicators of the effect. The main directions of the search for reserves are outlined: resource, technological, organizational.
\end{abstract}

Key words: reserves, foreign economic activity, efficiency, enterprise, analysis.

JEL Classification: M 41

DOI: https://doi.org/10.36477/2522-1256-2019-24-14

Постановка проблеми. Україна знаходиться на важливому етапі входження в систему світових господарських зв'язків, від успішної реалізації якого залежить не тільки динаміка зовнішньої торгівлі, але й можливість розвитку держави як органічної підсистеми світового господарства. Важливою умовою успішного функціонування системи зовнішньоекономічної діяльності України в комплексі міжнародного обміну є вдосконалення системи оцінки ії результатів.

Характерною ознакою становлення України як незалежної держави зі світовим рівнем розвитку національної економіки $є$ загальна зосередженість на дослідженні проблематики ефективного входження вітчизняного господарського комплексу до глобального ринку та посідання ним гідного місця у міжнародній системі.

Аналіз останніх досліджень і публікацій. Аналіз наукових праць 3 окресленої проблематики показав, що у вітчизняній i зарубіжній науковій літературі існує певний доробок щодо визначення зовнішньоекономічної діяльності (ЗЕД) таких українських науковців, як І. В. Бураковський, В. Р. Сіденко, В. І. Чужиков, А. С. Філіпенко, О. І. Кредісов, А. П. Румянцев, а також зарубіжних вчених: В. Парето, П. Х. Ліндерт, П. Хейне, Е. Дж. Долан, Г. Менкью, Д. Сальваторе, Р. С. Хеймані, Д. М. Шапіро.

В Україні у даний час не лише недостатньо розроблені теоретичні аспекти економічної ефективності зовнішньоекономічної діяльності підприємства, але дискусійними залишаються й питання про резерви ії підвищення.

В економічній літературі можна побачити різні тлумачення самого поняття “резерви”. В основному всі вони зводяться до таких формулювань:

а) "невикористані можливості підвищення ефективності і конкурентоздатності підприємства" [1, c. 29]; б) “кількісно співвимірні можливості підвищення ефективності виробництва за рахунок покращання використання виробничих ресурсів в результаті застосування досягнень науково-технічного прогреcy" [2, c. 29].

Постановка завдання. На основі викладеного вище можна сформулювати завдання дослідження, яке полягає у виявленні резервів зростання ефективності зовнішньоекономічної діяльності вітчизняних підприємств.

Виклад основного матеріалу дослідження. На нашу думку, під резервами розуміють можливі поліпшення, що характеризують ефективність зовнішньоекономічної діяльності підприємства. Резерви класифікують за кількома напрямами (табл. 1).

Така класифікація є узагальненою для здійснення економічного аналізу ЗЕД, тому вона найчастіше застосовується в межах локального аналізу підвищення його ефективності функціонування.

До організаційних резервів виробництва відносять втрати, які зумовили відхилення від нормального ходу діяльності, що відтворюються в планових показниках. Щоб віднайти резерв, потрібно вивчити фактори цих відхилень, розподілити їх на керовані та некеровані з точки зору менеджменту, визначити втрати, до яких привели некеровані фактори впливу. Визначення величини організаційного резерву можна спростити завдяки проведенню оцінки діяльності в галузі, що аналізується. Вона здійснюється за відхиленнями, які залежать від рівня управління.

До потенційних резервів відносять можливе поліпшення показників до рівня, який відтворює найкращий рівень діяльності підприємства. Розрахунок його проводять за формулами впливу факторів на узагальнений показник. Максимально залучити цей резерв неможливо. Але слід підкреслити, що він $є$ базою для розрахунку потужності робіт в аналізованій діяльності, яку оцінюють згідно з узагальненим показником. 


\section{Таблиия 1}

Класифікація резервів за різними ознаками*

\begin{tabular}{|c|c|}
\hline Класифікаційні ознаки & Резерви \\
\hline За змістом: & $\begin{array}{c}\text { техніко-технологічні; } \\
\text { економічні; } \\
\text { соціальні; } \\
\text { організаційні. }\end{array}$ \\
\hline $\begin{array}{c}\text { За обсягом розповсю- } \\
\text { дження }\end{array}$ & $\begin{array}{c}\text { загальні; } \\
\text { часткові (специфічні). }\end{array}$ \\
\hline За важливістю: & $\begin{array}{c}\text { основні; } \\
\text { другорядні. }\end{array}$ \\
\hline За місцем виникнення: & $\begin{array}{c}\text { галузеві; } \\
\text { внутрішньовиробничі. }\end{array}$ \\
\hline За структурою: & $\begin{array}{c}\text { складні (багатофакто- } \\
\text { рні); } \\
\text { прості (однофактор- } \\
\text { ні). } \\
\end{array}$ \\
\hline Залежно від часу дії: & $\begin{array}{c}\text { постійні; } \\
\text { тимчасові. }\end{array}$ \\
\hline $\begin{array}{c}3 \text { позицій управління як } \\
\text { цілісної системи: }\end{array}$ & $\begin{array}{l}\text { організаційні; } \\
\text { потенційні; } \\
\text { перспективні. }\end{array}$ \\
\hline
\end{tabular}

До перспективних резервів відносять можливе поліпшення показників до рівня, який відповідає всебічному впровадженню науково-технічного прогресу у виробництво. Розрахунок цього резерву проводять згідно з формулами впливу проміжних та похідних показників на узагальнений показник, а величина його залежить від спрямування та темпів упровадження наукових розробок у виробничий процес.

I врешті-решт на основі остаточної оцінки ЗЕД, впливу факторів на аналізований показник, вияву резервів формуються проблеми, що потребують невідкладного вирішення для підвищення ефективності ЗЕД. Сформулювавши проблеми, необхідно опрацювати рекомендації, що сприятимуть поліпшенню ситуації.

Виявлення резервів - надзвичайно важливий етап для розробки планових організаційнотехнічних заходів з метою підвищення ефективного функціонування підприємства. Обізнаність щодо резервів, а саме: їх величини і місць виникнення, дає змогу класифікувати їх за ступенем важливості, рівнем управління, часом дії.

Основні напрями пошуку резервів підвищення ефективності зовнішньоекономічної діяльності підприємства:

- ресурсний;

- технологічний;

- організаційний.

Ресурсний - відображає необхідність аналізу ефективності використання наявної матеріальної бази виробництва, а також живої праці, адже резервом підвищення ефективності ЗЕД $є$ ефективне прийняття рішень, пов'язане з розподілом ресурсів і зусиль підприємства між нарощуванням потенціалу і його використанням, а також між відтворенням i виробництвом. У залежності від виду ресурсів, які використовує підприємство, та їх впливу на результати господарської діяльності доцільно виділити небезпечні внутрішні фактори, здатні чинити негативний вплив на стабільність розвитку підприємства.

Виділяють дві "ресурсні" позиції. Перша - виробничий потенціал $є$ сукупністю ресурсів без урахування їх взаємозв'язку та участі в процесі виробництва. Особливість другої позиції полягає у трактуванні виробничого потенціалу як сукупності ре-сурсів, здатних проводити певну кількість матеріальних благ. Разом із ресурсним підходом до визначення сутності виробничого потенціалу спостерігаються і інші трактування. Так, Ю. Донець вважає виробничий потенціал синонімом виробничої по- тужності підприємства, об'єднання і тому вважає можливим визначати його як “максимально можливий річний, добовий, годинний або віднесений до іншої тимчасової одиниці об'єм випуску продукціі”' [3, с. 3]. На думку С. Воробйова, виробничий потенціал - це реальний обсяг продукції, який економіка в змозі виробити за умови повного використання наявних ресурсів [4, с. 363].

Аналіз вищевикладених точок зору приводить до висновку, що виробничий потенціал господарюючої системи - сукупність ресурсів, наданих в іiі розпорядження для творчої діяльності. Кількісні та якісні параметри цих ресурсів, а також їх інтеграція визначають виробничу здатність господарської ланки. Проте ви-робничий потенціал, визначаючи можливість випуску матеріальних благ і послуг, не може служити мірою корисного ефекту. Основне значення виробничого потенціалу підприємства полягає у створенні нових вартостей, а його елементи повинні цілеспрямовано адаптуватися до вимог продукції, що виготовляється. Це своє призначення виробничий потенціал зможе виконати, якщо прийнята ним речовинно-натуральна форма та кількісне співвідношення складових роблять його здатним функціонувати як вартість, що створює вартість і додаткову вартість. Тобто, коли склад і ха-рактеристики елементів виробничого потенціалу відповідають і визначаються параметрами продукції, що виготовляється.

Частина виробничих ресурсів, яка бере участь у певному циклі виробництва і в певному проміжку часу, може вважатися фактором (чинником) виробництва. Тобто виробничий потенціал лише тоді $€$ чинником виробництва, коли ресурси, що знаходяться в органічній єдності, здатні забезпечити виробництво продукції.

Види факторів виробництва зумовлені різноманітною виробничою діяльністю людини у багатьох галузях, сферах, підрозділах і регіонах. Робітники як чинники виробництва можуть бути зайняті у матеріальному виробництві чи духовній сфері, у різних регіонах країни тощо. Види факторів виробництва різноманітні, що є об'єктивною підставою суспільного поділу праці.

Види факторів виробництва характеризуються визначеністю. Вони представлені засобами виробництва 
(речовий чинник) і безпосередніми виробниками (особистий чинник), наділеними здатністю до праці (у тому числі до підприємницької діяльності), яка реалізується у поєднанні з засобами праці.

Функціонуванню та взаємодії чинників виробництва передує їх поєднання. Будь-який процес виробництва - це поєднання людей певним способом між собою та з відповідними речовими факторами. 3 метою приведення усіх чинників у рух потрібно знайти відповідні кількісні співвідношення між усіма речовими елементами виробництва та чисельністю працівників. Це завдання вирішує технологія, що визначає способи переробки різних видів ресурсів та одержання готових продуктів. 3 урахуванням кількісного аспекту між чинниками виробництва повинна дотримуватися відповідна пропорційність розмірів. Вона визначається технікотехнологічними параметрами виробництва. Наприклад, кількість працівників виробництва продукції визна-чається не тільки кількістю виробленої продукції, а й технологією іiї виробництва. Незбалансованість ресурсів у кількісному плані може призвести до того, що певний компонент виробництва здатен залишитися фактором можливого використання і не проя-вить себе як продуктивна сила.

Фактори виробництва повинні знаходитися між собою і у певній якісній відповідності.

Ресурсний та виробничий потенціали певною мірою сприймають як сумарно обчислені еквіваленти землі, трудових та фінансових ресурсів, виробничих засобів. Проте до складу природних ресурсів, крім землі, входять і опади, кількість інтенсивних світових днів, активних температур та ін.

Будь-який технологічний процес сучасності немислимий без технічних засобів, тобто відповідного устаткування, машин і механізмів, які беруть участь при виготовленні тих або інших продуктів.

Серед проблем, які виникають у процесі поєднання чинників виробництва, найсуттєвішими $є$ такі:

- забезпечення збалансованого розвитку засобів виробництва і трудових ресурсів, їхньої взаємної якісної та кількісної тотожності;

- формування і підтримання мотивації до освоєння прогресивніших засобів виробництва;

- заміна ручної, малокваліфікованої праці на технічно і технологічно оснащену, що дає змогу значно зменшити питомі витрати всіх ресурсів;

- досягнення оптимізованих пропорцій у разі формування техніко-технологічної бази виробництва і підготовки сучасного працівника;

- виявлення та освоєння нових, прогресивних форм включення працівників у виробничий процес;

- створення та утримання на належному рівні організаційно-економічного механізму управління процесом поєднання і використання чинників виробництва, за якого досягався б найбільший результат за найменших витрат.

Важливою складовою ефективності підприємства (а отже, і значним резервом іiї підвищення) є організація виробничого процесу. Слід проаналізувати всі аспекти, які визначають ефективність організації робіт, - від рівня робочого місця окремого робітника чи спеціаліста до рівня підприємства в цілому.
Ефективність організації виробничих процесів $€$ одним 3 джерел конкурентоспроможності та дієвості промислового підприємства. Вплив процесів розвитку виробництва на прийняття організаційних рішень поступово розширюється, i, якщо спочатку вони спиралися лише на трудові процеси, то сьогодні вони також включають і виробничі процеси підприємства. Організація виробництва взаємодіє 3 іншими елементами управління виробництвом, тому запровадження будь-яких нововведень повинно супроводжуватися змінами в самій системі управління підприємством [5, с. 320].

Показниками визначення ефективності ЗЕД підприємств є показники відносної й абсолютної ефективності експорту. Дослідження методологічних підходів щодо визначення ефективності зовнішньоекономічної діяльності підприємств виявили, що в сучасній економічній науці домінують два підходи.

Перший грунтується на розрахунку загального показника ефективності зовнішньоекономічної діяльності підприємства - прибутковості зовнішньоторговельних операцій.

Другий підхід полягає в обчисленні ефективності окремих укладених зовнішньоторговельних угод. У перебігу теоретичного дослідження авторами доведено, що існуючі методичні підходи не дозволяють провести комплексну оцінку ефективності зовнішньоекономічної діяльності підприємств, проаналізувати вплив чинників, які супроводжують діяльність підприємств на внутрішньому та зовнішньому ринку, виявити та оцінити резерви підвищення ефективності їх ЗЕД [6, с. 8].

Механізм визначення ефективності ЗЕД підприємств трактується як система методологічних підходів та прийомів, застосування яких дозволяє розрахувати ефективність ЗЕД підприємств, проаналізувати вплив чинників на результати цієї діяльності, а також виявити резерви та шляхи її підвищення:

- Комплексний аналіз експортно-імпортних операцій.

- Комплексний аналіз експорту (імпорту) підприємства.

- Обчислення й оцінка цінової ефективності експорту (імпорту) підприємства.

- Обчислення й оцінка абсолютної ефективності експорту (імпорту) підприємства.

- Визначення фактичної ефективності експорту (імпорту) підприємства.

- Обчислення резервів зростання ефективності експорту (імпорту) підприємства та визначення можливої ефективності.

- Обгрунтування комплексу заходів з реалізації резервів підвищення ефективності експорту (імпорту) підприємства.

Соціально-економічна сутність зовнішньоекономічних зв'язків виявляється в їх значенні для розвитку національної економіки, у вирішенні завдань внутрішньої та зовнішньої політики. ЗЕД вітчизняних підприємств визначається передусім експортноімпортними операціями, які можуть мати різні види та форми. Вид зовнішньоекономічних зв'язків характеризують напрямом товарного потоку (експортнi, імпортні) чи структурною ознакою. До форм 
зв'язку (зовнішнього прояву його сутності) відносять торгівлю, бартер, туризм, інжиніринг, франчайзинг, лізинг, інформаційний обмін, консалтинг тощо [7].

Визначення ефективності зовнішньоекономічних операцій проводиться для обгрунтування не лише окремих пропозицій щодо закупівлі та продажу певних товарів. Ці дані можуть бути використані при розробці планів експорту й імпорту в масштабах країни, при оцінці структури та напрямів зовнішньоторговельного обігу. Подібні розрахунки виконуються як у національній, так і в іноземній валюті.

При визначенні ефективності ЗЕД підприємств застосовується системний підхід, який надає можливість здійснити комплексний аналіз будь-якого виду зовнішньоекономічної операції. Для проведення економічного аналізу потрібно обрати критерій ефективності. На основі такої ознаки здійснюється кількісна оцінка ефективності виробництва. Згідно 3 цим визначенням обраний критерій має відповідати принципам побудови показників ефективності, а також всебічно відтворювати ії економічну сутність [8].

На основі похідних даних можна вирахувати часткові та узагальнений показники, побудувати факторну модель, розробити формули впливу факторів на узагальнений показник, вирахувати можливі відхилення при здійсненні фінансово-господарської діяльності, обчислити резерви та обгрунтувати проблеми, які потребують негайного вирішення на управлінському рівні.

Економічне обгрунтування діяльності підприємств, у тому числі і тих їх напрямків, які пов'язані iз зовнішньоекономічною сферою господарювання, здійснюється на підставі аналізу показників ефективності.

Показники економічної ефективності ЗЕД поділяють на:

1) показники ефекту, що визначаються як абсолютні значення і відтворюються в грошових одиницях як різниця між результатами діяльності та витратами на ії здійснення;

2) показники ефективності, що визначаються як співвідношення прибутку від діяльності підприємства до витрат на іii здійснення i відтворюються відносними величинами: відсотками, частками одиниці.

Розрахунок показників ефективності вимагає дотримання таких принципових методологічних положень:

1) принципу всебічного обліку всіх складових елементів витрат та результатів, який припускає якісну класифікацію і відтворення відповідних показників у документах оперативного, статистичного i бухгалтерського обліку;

2) принципу зведення витрат і результатів. Для зіставлення показники, які порівнюються, повинні відтворюватися однаковими кількісними одиницями i носити антонімічний характер в економічному розумінні. При конструюванні показника ефективності чисельник і знаменник останнього мають виключати можливе дублювання складових елементів;
3) принципу зведення різнотермінових витрат i результатів до одного моменту часу за допомогою дисконтування;

4) принципу зіставлення 3 базовим варіантом, що відтворює сутність застосування показників ефективності для здійснення економічного аналізу, який проводять не тільки 3 метою опису поточного стану діяльності суб'єкта господарювання, а й 3 метою опрацювання пропозицій щодо поліпшення економічної ситуації, яка склалася в періоді, що аналізується [9].

Здійснюваний економічний аналіз полягає у вивченні поточного стану підприємства в галузі ЗЕД, його відхилень від запланованого рівня та виявленні факторів, що спричинили ці відхилення. Він $є$ базою для прийняття управлінських рішень, тому має за мету:

1) оцінити діяльність підприємства та його підрозділів;

2) виявити можливі резерви;

3) сформулювати проблему, яку слід вирішити.

Оцінка діяльності здійснюється шляхом зіставлення фактичних результатів із запланованими або за попередній період. Можливою вважається і оцінка відносно нормативних показників або показників аналогічних підприємств.

Однією $з$ найважливіших особливостей аналізу є його тривалість у часі. Від цього залежить перелік етапів аналізу і послідовність його проведення. Визначення оптимального співвідношення між терміном проведення та глибиною аналізу - не менш важлива проблема. Одним зі шляхів вирішення проблемної ситуації є системний підхід.

Структуру аналізу можна пояснити так: він починається $з$ найвищого рівня управління або узагальненого показника, далі визначається коло факторів, які впливають на важливі складові, а наприкінці обираються показники, за допомогою яких здійснюється економічний аналіз [10, с. 24-32].

Основою започаткування факторної моделі можна вважати розробку формул розрахунку впливу факторів на узагальнений показник. Інструментарієм такого процесу є спосіб “ланцюгових підстановок”, сутність якого полягає в тому, що вплив різних факторів на узагальнений показник визначається шляхом послідовної заміни базових значень про- міжних показників на ті, що аналізуються. За таких умов у першу чергу заміна здійснюється за кількісними показниками, а потім - за якісними. Якщо ж у формулі декілька кількісних і якісних показників, то послідовність підстановок визначається економічною логікою процесу.

Висновки і перспективи подалыших досліджень у даному напрямі. Подальший розвиток економіки України повинен бути пов'язаним з тією економічною стратегією, яка орієнтована на розвиток ЗЕД, експортно орієнтованих галузей та підприємств, підвищення конкурентоздатності продукції вітчизняних виробників.

Для підвищення рівня відкритості української економіки необхідно створювати для підприємств 
більш сприятливі умови щодо виходу на зовнішні ринки. Широкий вихід підприємств на зовнішні ринки може бути ефективним лише у тому випадку, якщо спеціалісти у галузі ЗЕД оволодіють теорією та практикою здійснення зовнішньоекономічних операцій. Виходячи з цього, перспективою подальших досліджень $є$ систематизація та узагальнення закономірностей, умов, принципів, процесів здійснення ЗЕД підприємств, забезпечення більш глибокого розуміння іiї стратегічних та процедурних аспектів.

\section{ЛІТЕРАТУРА}

1. Анализ и обоснование хозяйственных решений [Текст] / [Б. И. Майданчик, М. Г. Карпунин, Я. Г. Люминецкий и др.]. - М. : Финансы и статистика, 1991. - 133 с.

2. Анализ эффективности хозяйственной деятельности промышленных объединений и предприятий [Текст] : справочник / [Л. Л. Ермолович, В. В. Ермолович и др.]. - Мн. : Вишэйшая школа, 1988. - $496 \mathrm{c}$.

3. Донец Ю. Ю. Эффективность использования производственного потенциала / Донец Ю. Ю. - К. : Знание, 1998. - 123 с.

4. Воробйов С. М. Економіка. Довідник старшокласника та абітурієнта / Воробйов С. М. - Х. : ТОРСІНГ ПЛЮС, 2005. - 400 с.

5. Гребельник О. П. Основи зовнішньоекономічної діяльності : підручник / О. П. Гребельник. [3-тє вид., перероб. та доп.]. - К. : Центр навчальної літератури, 2011. - 432 с.

6. Бакуменко В. Д. Методологія системних досліджень в державному управлінні : навч. посібник / Бакуменко В. Д., Кравченко С. О. - К. : ВПЦ AMУ, 2011. - $116 \mathrm{c}$.

7. Зовнішньоекономічна діяльність підприємств [Електронний ресурс]. - Режим доступу: http://library.if.ua/book/53/3850.html.

8. Зовнішньоекономічна діяльність підприємств : навчальний посібник / [Козак Ю. Г., Логвінова Н. С. та ін.; за ред. Ю. Г. Козака, Н. С. Логвінової, М. А. Зайця]. - [4-тє вид., перероб. та доп.]. К. : Освіта України, 2012. - 272 с.
Підприємництво і торгівля. 2019. Вип. 24.

9. Шурпенкова Р. К. Організація і методика економічного аналізу : навч. посібник / Р. К. Шурпенкова, І. І. Демко. - К. : УБС НБУ, 2011. - 287 с.

10. Цебекова Е. П. Анализ внешнеэкономической деятельности предприятия / Е. П. Цебекова // Финансы, Экономика, Стратегия. - 2011. № 11. - С. 24-32.

\section{REFERENCES}

1. Analyz y obosnovanye khoziajstvennykh reshenyj [Tekst], B. Y. Majdanchyk, M. H. Karpunyn, Ya. H. Liumynetskyj y dr. (1991), Fynansy y statystyka, M., $133 \mathrm{~s}$.

2. Analyz efektyvnosty khoziajstvennoj deiatel'nosty promyshlennykh ob'edynenyj y predpryiatyj [Tekst]: spravochnyk, L. L. Ermolovych, V. V. Ermolovych y dr. (1988), Vyshejshaia shkola, Mn., 496 s.

3. Donets, Yu. Yu. (1998), Effektyvnost' yspol'zovanyia proyzvodstvennoho potentsyala, Znanye, K., $123 \mathrm{~s}$.

4. Vorobjov, Ye. M. (2005), Ekonomika. Dovidnyk starshoklasnyka ta abituriienta, TORSINH PLYuS, Kh., $400 \mathrm{~s}$.

5. Hrebel'nyk, O. P. (2011), Osnovy zovnishn'oekonomichnoi diial'nosti: pidruchnyk, 3 nd ed, Tsentr navchal'noi literatury, K., $432 \mathrm{~s}$.

6. Bakumenko, V. D. and Kravchenko, S. O. (2011), Metodolohiia systemnykh doslidzhen' v derzhavnomu upravlinni: navchal'nyj posibnyk, VPTs AMU, K., $116 \mathrm{~s}$.

7. Zovnishn'oekonomichna diial'nist' pidpryiemstv, available at: http://library.if.ua/book/ 53/3850.html.

8. Zovnishn'oekonomichna diial'nist' pidpryiemstv: navchal'nyj posibnyk, Kozak Yu. H., Lohvinova N. S. ta in. (2012), 4 nd ed, Osvita Ukrainy, K., 272 s.

9. Shurpenkova, R. K. and Demko, I. I. (2011), Orhanizatsiia i metodyka ekonomichnoho analizu: navch. posibnyk, UBS NBU, K., $287 \mathrm{~s}$.

10. Tsebekova, E. P. (2011), Analyz vneshneekonomycheskoj deiatel'nosty predpryiatyia, Fynansy, Ekonomyka, Stratehyia, № 11, s. 24-32.

Стаття надійшла до редакиії 5 лютого 2019 р. 